\title{
Impact of natural fires on the vegetation cover of steppe and forest-steppe zones (European part of Russia, Middle Volga region)
}

\author{
Valentina Ilyina ${ }^{1,{ }^{*}}$, Anna Mitroshenkova ${ }^{1}$, Stepan Senator $^{2}$, Vera Solovyeva ${ }^{1}$, and \\ Stanislav Rogov ${ }^{1}$ \\ ${ }^{1}$ Samara State University of Social Sciences and Education, 443090, Antonov-Ovseenko str., 26, \\ Samara, Russia \\ ${ }^{2}$ Tsitsin Main Botanical garden of the Russian Academy of Sciences, 127276, Botanicheskaja str., 4, \\ Moskow, Russia
}

\begin{abstract}
The effect of natural fires on the vegetation cover of steppe and forest-steppe zones in the south-east of European Russia (the middle course of the Volga River) has been evaluated. The research used methods of studying biosystems at organism, species, population and cenotic levels. The study revealed the possibility of regrowth of aboveground plant parts after fires, changes in the population structure of species, and resistance of populations and zonal plant communities to the effects of natural fires. The most vulnerable among zonal vegetation types are pine forests, feathergrass and petrophytic steppes. Frequency, intensity and area of natural fires in the Middle Volga region cause significant changes in the structure of vegetation cover and reduction of biodiversity. The results obtained in the study of the impact of fires on vegetation can be used in the planning and implementation of environmental and reforestation measures.
\end{abstract}

\section{Introduction}

Preventing and combating natural fires has become a global environmental problem [18], as is clearly shown by the unfortunate events that occur annually on almost all continents.

Natural fires are one of the main ecological factors that have a significant impact on almost the entire spectrum of zonal ecosystems (pine and pine-broadleaved forests, meadow and mixed steppes) in the Middle Volga basin. Practically all arising natural fires are related with economic and recreational activities of the population (Fig. 1). In some cases, they are associated with deliberate arson. The scale of fires is exacerbated to the level of catastrophic fires due to the aridity of the climate in the study area (rainfall in some years does not exceed $300 \mathrm{~mm}$ ), as well as the untimely response of fire departments, insufficient fire prevention measures, lack of equipment and human resources during extinguishment.

The role of natural fires is not always evaluated negatively, there are positive aspects too. For example, it is the clearing of steppe communities from steppe mat, the destruction

* Corresponding author: $\underline{5 \text { iva } @, \text { mail.ru }}$ 
of some pests and fungal diseases of plants and animals and others. At the same time, fires in the forest-steppe and steppe zones of the south-east of European Russia have more of a negative rather than stimulating effect on the development of vegetation cover and related components of ecosystems. The Middle Volga region is characterized by a high degree of economic development, the preserved areas with natural vegetation cover have a small area, and natural fires are a rather critical phenomenon. Small areas of steppe vegetation (Figs. $2,3)$, located disjunctively, are particularly susceptible to the pyrogenic factor when restoration of natural vegetation cover is impossible due to the transfer of plant buds.

The aim of this work is to characterize the main trends of vegetation cover development in the Middle Volga basin after the impact of natural fires.

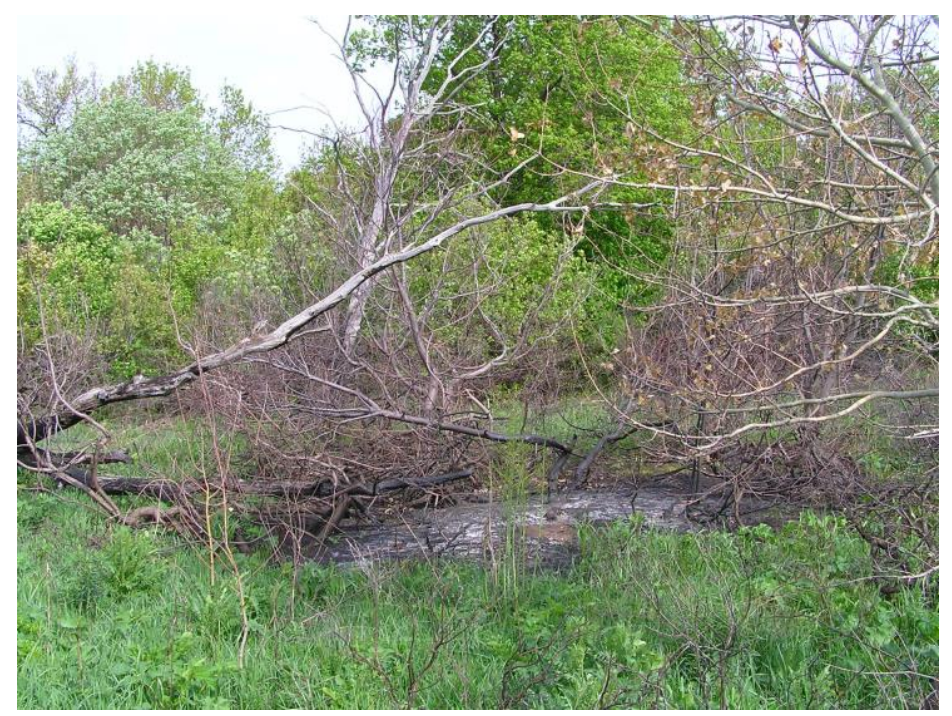

Fig. 1. Consequences of forest fire and restoration of herbaceous vegetation (photo by V. Ilyina).

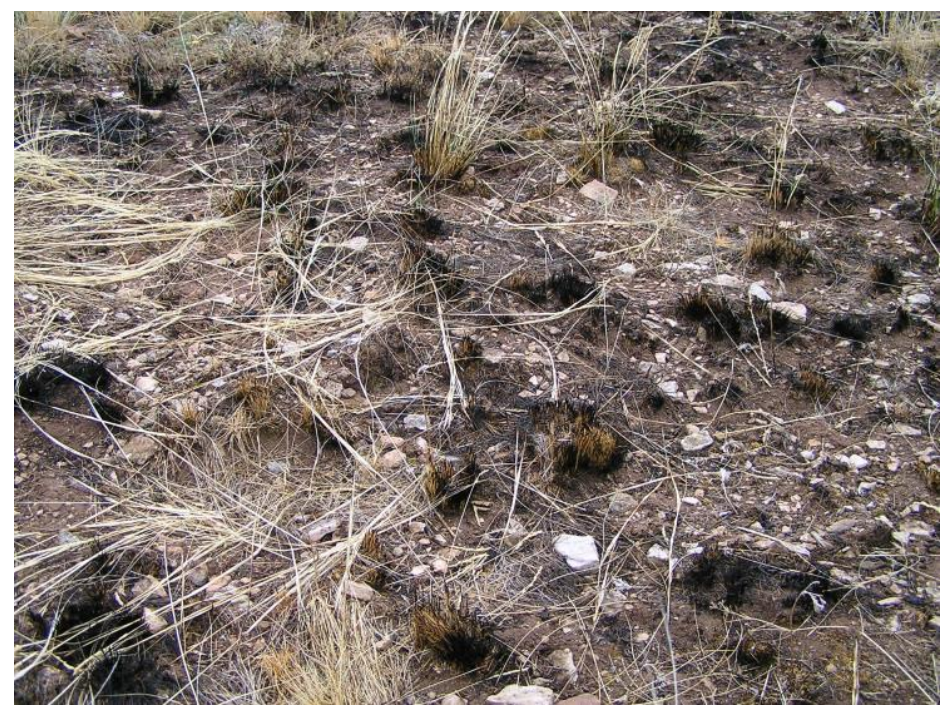

Fig. 2. The consequences of steppe phytocenosis burning (photo by V. Ilyina). 


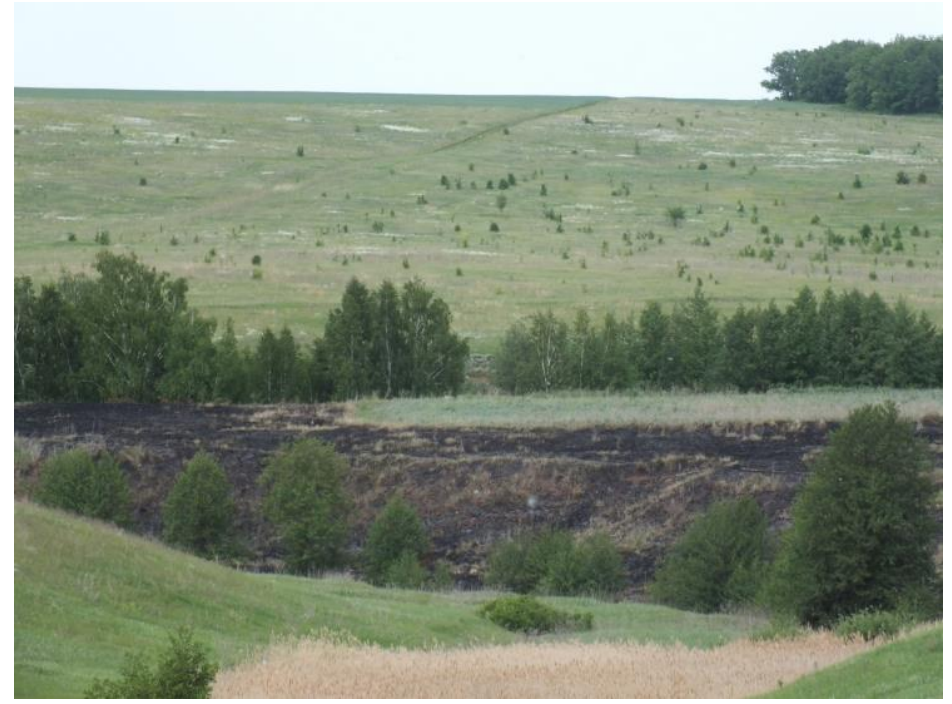

Fig. 3. Consequences of the steppe fire (photo by V. Ilyina).

\section{Materials and Methods}

The study area is located in southeastern European Russia in the middle course of the Volga River between $54^{\circ} 88^{\prime} 7903^{\prime \prime} \mathrm{N}$ and $51^{\circ} 77^{\prime} 4088^{\prime \prime} \mathrm{N}$ and $45^{\circ} 79^{\prime} 79^{\prime \prime} \mathrm{E}$ and $52^{\circ} 56^{\prime} 6412^{\prime \prime} \mathrm{E}$. The climate of the region is continental, with sharp temperature contrasts, short transitional seasons, cold winters, hot summers, moisture deficit, high solar radiation, and high probability of spring and fall frosts. The amount of annual precipitation from the northern boundary of the region to the southern boundary decreases from 400 to $250 \mathrm{~mm}$. Duration of the vegetation period from north to south increases from 130 to 160 days. Chernozem, gray forest, dark chestnut and alluvial (floodplain) soil types are typical for the Middle Volga region. Natural conditions also determine the background vegetation cover, which is represented by forest, steppe and meadow communities.

The study of fire impact on vegetation cover of the Middle Volga region was conducted in 2004-2020 on the territory of the Middle Volga basin. The stationary, semi-stationary and laboratory methods were used to conduct the research. Research was carried out at organism, species, population and phytocenotic levels. The abundance of individual species was recorded; the spatial, ontogenetic vitality structure of plant populations was determined; the main successional processes in plant communities and the dynamics of the number of some of their constituent species were identified [9-12].

\section{Results and Discussion}

The research revealed the fact of negative influence of pyrogenic factor on vegetation cover. Fires affect the state and structure of populations of various species, including protected species. Article shows the results of the study of the processes of regrowth of above-ground parts of plants after fires.

The process of burning organs of perennial herbaceous plants is influenced by the intensity and season of fire. In the spring period (mid-end of May), all above-ground parts of the individuals that started vegetation are destroyed. After some time, the vegetative parts of adults may regrow from resting buds of renewal. In this case, plants of virginile 
(especially seedlings) and senile periods are almost completely destroyed. In general, vegetation of adults is delayed by 1-2 weeks, which manifests itself in displacement of all subsequent phenological phases.

When assessing the impact of fires on vegetation cover, it is necessary to take into account the duration of fire, as well as the area and periodicity of fire occurrence. If occasional fires and burns are repeated from year to year, the number of emerging seedlings decreases exponentially. The insignificant seed bank and the high degree of mortality of juvenile plants lead to the gradual aging of the population (characterized by a right-sided ontogenetic spectrum with a predominance of old-age plants) and the inevitable decrease in its number.

Low intensity of regrowth of vegetative parts of individuals of some species after fires: Artemisia salsoloides, Astragalus temirensis, A. zingeri, Atraphaxis frutescens, Globularia punctata, Goniolimon elatum, Ephedra distachya, Eremogone koriniana, Hedysarum razoumovianum, Iris pumila, Linum flavum, L. perenne, L. uralense, Medicago cancellata, Nepeta ucranica, Onosma polychroma.

Average intensity of regrowth: Adonanthe vernalis, A. volgensis, Ajuga glabra, Alyssum lenense, Anthemis trotzkiana, Astragalus cornutus, A. helmii, A. sulcatus, A tenuifolius, A. ucrainicus, A. wolgensis, Centaurea sibirica, Clausia aprica, Crambe tataria, Dianthus leptopetalus, Ferula tatarica, Hedysarum gmelinii, H. grandiflorum, Helianthemum nummularium, Jurinea ewersmannii, J. ledebourii, J. multiflora, Ornithogalum fischeranum, Oxytropis hippolyti, O. spicata, Pleurospermum uralense, Polygala sibirica, Scabiosa isetensis, Schivereckia hyperborea, Tulipa schrenkii.

High intensity of regrowth: Aster alpinus, Astragalus macropus, Cephalaria uralensis, Galatella angustissima, Dictamnus caucasicus, Ferula caspica, Laser trilobum, Oxytropis floribunda, Syrenia cana, Valeriana tuberosa.

Fires have a serious impact on the structure of phytocenoses and their further development. Resistance of plant communities to fire impacts is related to both the composition of life forms and ecological groups of constituent species, their ability to regrow, and the presence of anatomical and morphological adaptations. Frequency, intensity and time of fires have specific parameters and influence the degree of transformation of the plant community.

The saturation of tissues with water explains the greater resistance of mesophytes and hygrophytes to runaway fires in general. However, even coastal-water phytocenoses (monodominant communities of Typha angustifolia L. and T. latifolia L.) are often burned when aboveground plant parts dry out at the end of the growing season.

Different classes of fire danger in forests cause low fire resistance of pine forests of the region. High mortality (up to $75 \%$ of individuals) of pine stands is noted for individuals with a trunk diameter up to $15-16 \mathrm{~cm}$ at the base, $10-12 \mathrm{~cm}$ at $1,5 \mathrm{~m}$ from the soil surface and up to $20 \mathrm{~m}$ in height. Resistance to ground fires of average intensity is minimal for pine with trunk diameter at the base less than $7 \mathrm{~cm}$, and $97-99 \%$ of individuals are likely to die.

Oaks are the most negatively affected species by fires in broad-leaved forests of the region. During a low fire of average intensity, high mortality (over 60\%) is noted for individuals with trunk diameter up to $20 \mathrm{~cm}$ at the base, up to $15 \mathrm{~cm}$ at $1,5 \mathrm{~m}$ from the soil surface, and up to $10-12 \mathrm{~m}$ in height. Individuals with a trunk diameter of up to $10 \mathrm{~cm}$ at the base, $12-13 \mathrm{~cm}$ at $1.5 \mathrm{~m}$ from the soil surface, and up to $10-12 \mathrm{~m}$ in height and up to 5-6 $\mathrm{m}$ in height are completely destroyed.

Steppe communities are also very sensitive to fires, especially petrophytic steppes with low projective coverage of soil by herbage and feather grass steppes with high content of dry plant residues and steppe mat. In case of fires of average intensity, petrophytic steppes recover within 10-12 years, while feather-grass steppes - within 6-9 years. 


\section{Conclusions}

Studies of the current state of the vegetation cover of steppe and forest-steppe zones in the Middle Volga region (southeastern European Russia) allowed to identify natural fires among the limiting factors that cause changes in the structure and functional organization of phytocenoses. The most critical is the conservation of steppe and pine forests in the southeast of European Russia. The protection of plant cover and associated fauna and soil diversity in the Middle Volga Region is organised with publishing of the Red Books of the federal and regional levels $[13,14]$ and with the organized system of specially protected natural areas. However, in the current situation, when fires have a high frequency and intensity, more effective measures to prevent and extinguish fires are needed.

\section{References}

1. E. M. Lavrenko, Botanicheskii Zhurnal, 1, 77-78 (1950)

2. S. M. Old, Ecological Monographs, 39 (4), 355- 384 (1969)

3. I. Tuvshintogtokh, U. Magsar, International Forest Fire News (IFFN), 36, 67-75 (2007)

4. J. D. Bates, E. Rhodes, K. Davies, R. Sharp, Rangeland Ecology and Management, 62(1), 98-110 (2009)

5. V. N. Ilyina, Samarskaya Luka: problems of regional and global ecology, 2, 4-30 (2011)

6. M. J. A. Werger, M. A. van Staalduinen, (Eds.), Eurasian Steppes, Ecological Problems and Livelihoods in a Changing World. (2012)

7. S. L. Winter, K. R. Hickman, C. L. Goad, S. D. Fuhlendorf, M. S. Gregory, Natural Areas J., 33 (3), 327-338 (2013)

8. G. Kh. Dusaeva, O. G. Kalmykova, N. V. Dusaeva. Nature Conserv. Res., 4(1), 78-92 (2019)

9. Field geobotany, 3 (Publishing house of AS USSR, Moscow, 1964)

10. Field geobotany, 4 (Nauka,Leningrad, 1972)

11. L. A. Zhukova, Diversity of ontogenic pathways in plant populations. Rus. J. of Ecology, 32 (30), 151-158 (2001)

12. G. Yu. Sofronov, N. V. Glotov, S. M. Ivanov, AIP Conf. Proc., 1651, 118-127 (2015)

13. Red Book of the Samara Oblast. Rare species of plants and fungi, 1, (2017)

14. Red Book of the Russian Federation (plants and mushrooms) (2008) 